\title{
PORROGLOSSUM RAOI, A NEW SPECIES OF PLEUROTHALLIDINAE (ORCHIDACEAE) FROM ECUADOR
}

\author{
Luis E. Baquero R. ${ }^{1-4} \&$ Gabriel A. Iturralde ${ }^{1}$ \\ ${ }^{1}$ Carrera de Ingeniería Agroindustrial y Alimentos. Facultad de Ingeniería y Ciencias Agropecuarias. \\ Universidad de Las Américas, Calle José Queri, Quito 170137, Pichincha, Ecuador \\ 2 Jardín Botánico de Quito, Pasaje \#34, Rumipampa E6-264 y Av Shyris, Interior Parque La Carolina, \\ Quito, 170135, Pichincha, Ecuador. \\ ${ }^{3}$ Instituto Nacional de Biodiversidad, Pasaje Rumipamba 341 y Av. de los Shyris, 170135, Quito, \\ Pichincha, Ecuador \\ ${ }^{4}$ Correspondent author: lbaquero@hotmail.com
}

\begin{abstract}
A new species of Porroglossum (Pleurothallidinae), Porroglossum raoi Baquero \& Iturralde, apparently endemic to a cloud forest close to Chical, is described here. Porroglossum raoi is compared to known species within the genus growing close to the area where it was discovered. The big white flower, the thick, subclavate and brown-purple lateral sepal tails, a single subacute angle on the lower margin of the petals and a strong cinnamon and clove smell, immediately separates this from other species in Porroglossum. Taxonomical and ecological notes are given.
\end{abstract}

Key words: Pleurothallidinae, Porroglossum hoijerii, Porroglossum section Porroglossum

Introduction. The genus Porroglossum Schltr. was proposed by Schlechter in 1920 when some of the species previously placed in Masdevallia Ruiz \& Pav. did not seem to fit among the rest of species in this genus. 55 species of Porroglossum are known at the moment (Luer 1987, Dodson 2003, Merino, Doucette \& Pupulin 2010, Chase et al. 2015, Karremans 2016), and new taxa continue to be added to the list (Luer 2010, 2011, Luer \& Thoerle 2012, 2013, Doucette, McDaniel, Merino, Portilla \& Cameron 2015). The most remarkable feature of the flowers of Porroglossum is the trigger-sensible lip, something that is otherwise only in Masdevallia teaguei Luer, and some species belonging to Specklinia Lindl. (ex Acostaea Schltr.) and Stelis (ex Condylago Luer). Porroglossum is one of the three genera in the Pleurothallidinae with a lip capable of moving when affected by an external stimulus (Luer 1987). A change in turgor in a layer of cells from a tiny structure of the lip called the claw, causes it to move into a "closed" position on where the callus of the lip presses against the frontal surface of the column-foot (Sweet 1970, Luer 1987). Some species of Porroglossum, section Porroglossum (Luer 1987), have glabrous peduncles and big, expanded, dorsal sepals, wider than the synsepal formed by the fused lateral sepals, the apex of the dorsal sepal, with a longer or shorter tail, reflected towards the ovary. Species exhibiting such characteristics include Porroglossum actrix Luer \& Escobar, P. amethystinum (Rchb. f.) Garay, P. aureum Luer, P. hoeijeri Luer, P. josei Luer, P. marniae Luer, P. nutibara Luer \& Escobar, P. olivaceum Sweet, P. rodrigoi Sweet, $P$. sergioi P. Ortiz and P. teaguei Luer. Except for $P$. actrix, from Putumayo department in Colombia, the rest of the species grow on the western slopes of the Andes from Colombia and Ecuador (Luer 1980, 1987, 1988, 1989, 1991, 1994, 1995, 1998, 2006).

The north-western cloud forests of Carchi and Esmeraldas provinces in Ecuador are an area in which some species such as Porroglossum aureum, $P$. hoeijeri and P. josei have been discovered (Luer 1987, 1995). Before 2008, the only way to reach Maldonado and Chical, in Carchi province, was through Tulcán, the biggest city near the Ecuador-Colombia border. This meant a long trip, first, going north to Tulcán and, from there, driving west until getting to Maldonado and Chical. Porroglossum aureum and P. hoeijeri were discovered along the Tulcán-Maldonado road. In 2008, the road that connects Chical to el Carmen (E187) was officially opened; this allowed the access to previously unexplored zones. Through the E187 road, not only the possibility to reach certain unexplored areas was 
possible, but also, a faster way from Quito and most of Ecuador. Porroglossum eduardii (Rchb. f.) Sweet is one of the species which can be found growing along the new road at about $2300 \mathrm{~m}$ very close to where populations of $P$. hoeijeri thrive. Both species grow within a private protected area called Dracula Reserve, managed by the Ecominga foundation. A new species of Porroglossum has been discovered in this area, near the $14^{\text {th }} \mathrm{km}$ in the Chical-El Carmen road; Porroglossum raoi Baquero \& Iturralde is described below.

Porroglossum raoi Baquero \& Iturralde, sp. nov. (Figs. 1-2).

TYPE: Ecuador. Carchi, El Carmen-Chical road, $0^{\circ} 52^{\prime} 54.5^{\prime} \mathrm{N}$ 78¹3'20.7’'W, 1972 m, Luis Baquero 3045 (holotype, QCNE).

Diagnosis. Species similar to Porroglossum aureum from which it differs in the proportionally longer inflorescence, the white flowers with brown-purple, sub-clavate tails, a shortly elevated keel in the broadly thickened callus of the lip, the lower margin of the petals with a subacute angle near the middle and a characteristic cinnamon and clove fragrance, not detected in any other species of Porroglossum.

Plant caespitose, epiphytic, medium in size 6-13 $\mathrm{cm}$ tall. Roots slender, flexuous, $1 \mathrm{~mm}$ in diameter. Ramicauls abbreviated, terete, erect, slender, $10-40 \mathrm{~mm}$ long, enclosed by two or three tubular sheaths. Leaf erect, coriaceous, minutely verrucose, long petiolate, $5-9 \mathrm{~cm}$ long including the petiole; the blade $3-5 \times 0.8-1.2$ $\mathrm{mm}$, narrowly obovate; the apex subacute, mucronate; the base narrowed into a slender, conduplicate petiole $2.0-4.5 \mathrm{~cm}$ long. Inflorescence congested, successively few-flowered (three to five flowers) raceme; peduncle $20 \mathrm{~cm}$ long, slender, glabrous, erect to suberect, with a few widely spaced, thin, translucent bracts, floral bracts tubular, imbricating, 8-9 mm long; pedicel 10-13 mm long; ovary smooth, sparsely pocked, $4-5 \mathrm{~mm}$ long. Flowers resupinate, with a detectable cinnamon and clove fragrance. Sepals translucent white; the dorsal sepal depressed obovate, bilobed, 3-veined, $5 \times 10$ $\mathrm{mm}$ expanded, spotted with purple subulated short hairs and more densely covered throughout the veins, gradually increasing in density towards the apex and the tail, connate to the lateral sepals for $3 \mathrm{~mm}$ to form a gaping cup; the apex acutely reflexed, obtuse, minutely apiculate, abruptly contracted into a conduplicate tail 3 $\mathrm{mm}$ long that does not reach the ovary; the lateral sepals oblong, oblique, glabrous, 3-veined, 6-7×4 mm, connate $5 \mathrm{~mm}$ to form an acute mentum below the columnfoot; the apices oblique, acute, contracted into slender, brownish-purple tails, thickened along the middle, 11 mm long. Petals translucent yellow, the color intensity gradually increasing towards the apex, with a redpurple, translucent midvein, ovate-lanceolate, glabrous, $5 \times 2 \mathrm{~mm}$ narrowed to the slightly dilated, rounded, sub falcate apex; the lower margin with a subacute angle near the middle; the upper margin obtusely angled near the middle. Lip white, suffused with dispersed purple dots, sensitive and actively motile; the blade widely obtrullate, $5 \times 4 \mathrm{~mm}$; the broadly thickened callus with a shortly elevated keel running longitudinally towards the base; the apex minutely pubescent, acute, with a sulcus running $2 \mathrm{~mm}$ from the apex to the center of the blade; the base deflexed and hinged to the free apex of the column-foot by a strap-like claw. Column white, stout, semiterete, $3.5 \mathrm{~mm}$ long, with two tooth-like processes near the stigma; the column-foot slender, curved, $4 \mathrm{~mm}$ long. Pollinia 2, droplet shaped, each with a glandular caudicle. Fruits and seeds not seen.

Eponymy: Named in memory of the late Velliyur "Malli" Rao and his wife (from Wilmington, Maryland), important donors and promoters of Ecominga Foundation who made possible the purchase and protection of an extensive area of primary forest close to where Porroglossum raoi was discovered and other native forests around Ecuador.

Distribution: Porroglossum raoi is known for several plants found growing in primary cloud forest, at an elevation of $\sim 1900 \mathrm{~m}$, around $\mathrm{km} 14$ of the Chical-El Carmen road in the Province of Carchi, Ecuador.

Habitat and Ecology: Several plants of Porroglossum raoi, including the type specimen, have been found growing as epiphytic in extremely humid cloud forest between the $1890 \mathrm{~m}$ and $1970 \mathrm{~m}$ above sea level. Individuals of this species were growing sparsely, between direct sunlight and heavy shade in the understory of the cloud forest. No other Porroglossum species were found growing sympatrically with $P$. raoi while 


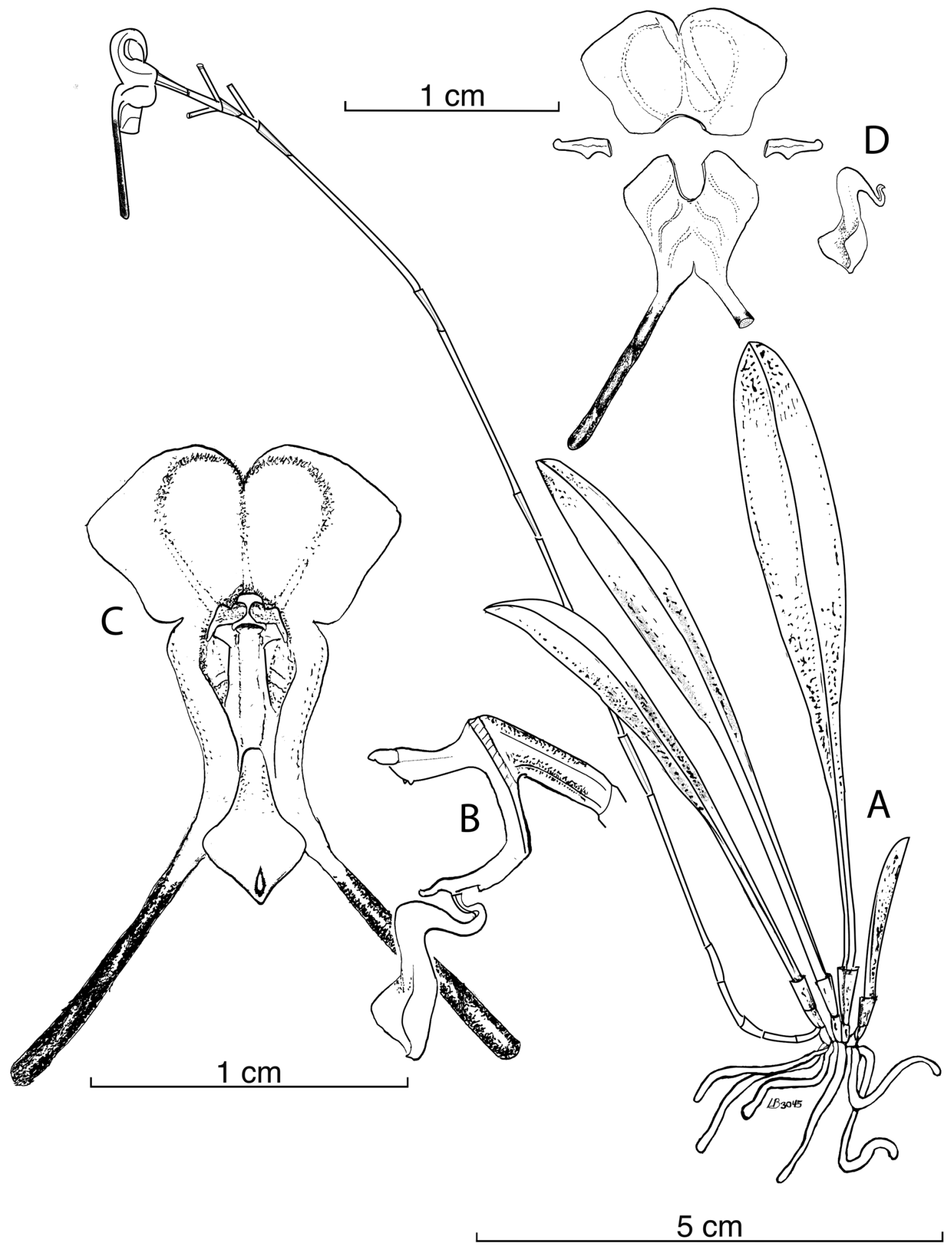

Figure 1. Porroglossum raoi. A. Habit. B. Column and lip, lateral view. C. Flower, front view. D. Dissected perianth. Drawn by Luis Baquero from the holotype. 


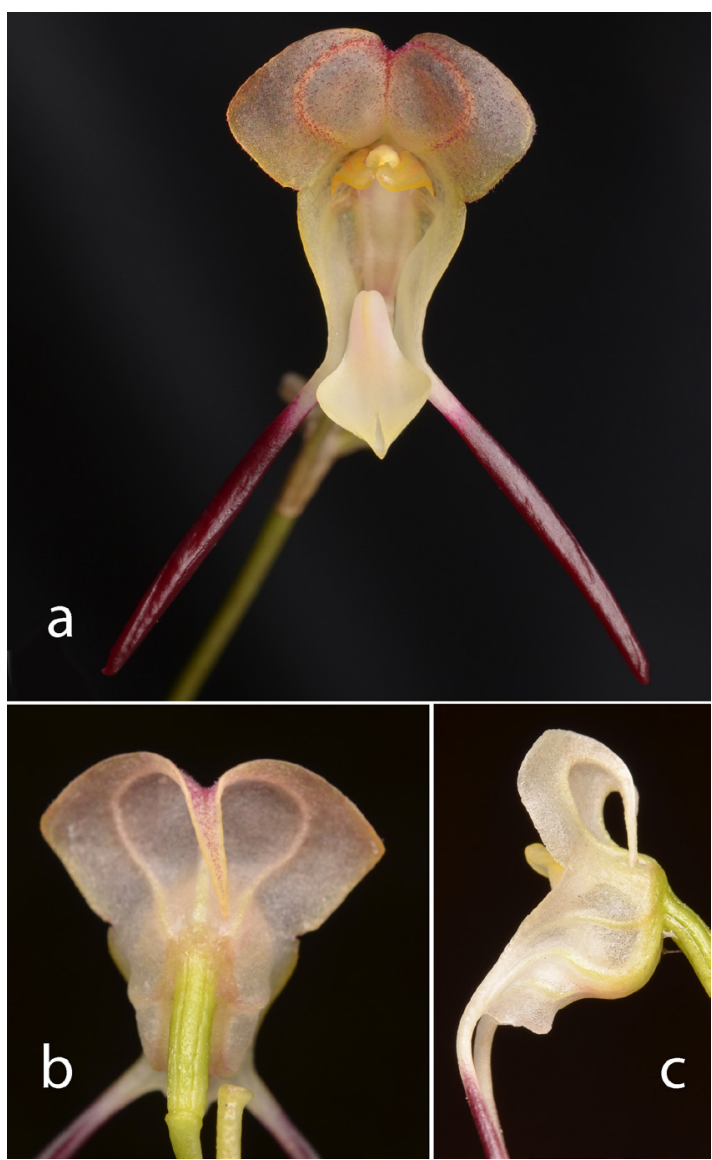

Figure 2. Flower of Porroglossum raoi. A. Frontal view. B.

View from behind. C. Lateral view.

other Pleurothalliidinae grow sympatrically: Dracula trigonopetala Gary Mey. \& Baquero ex A.Doucette, Scaphosepalum swertiifolium (Rchb. f.) Rolfe, Brachionidium imperiale Luer \& R. Escobar, Lepanthes hexapus Luer \& R. Escobar. Porroglossum raoi has not been reported outside its type locality, further field research could result on finding these species in other localities including the neighbor Colombia.

Conservation status: Because of its limited range of distribution and the risk of deforestation in the type locality, Porroglossum raoi should be considered as endangered or critically endangered by the IUCN criteria. Although it has not been found elsewhere, hopefully a healthy population of $P$. raoi thrives inside Dracula Reserve of the Ecominga Foundation, which exists close to where this species has been discovered.
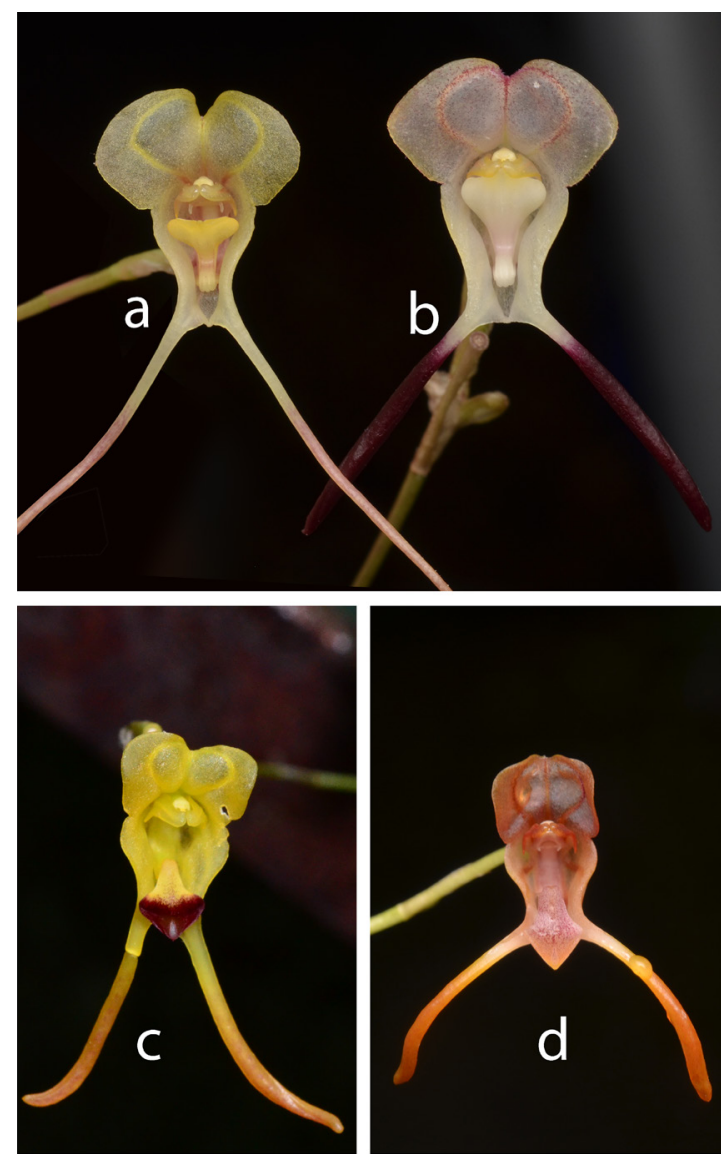

Figure 3. Flowers of four species of Porroglossum. A. P. aureum. B. P. raoi. C. P. marniae. D. P. olivaceum.

Porroglossum raoi is considered as a different species by a unique combinations of features, being the strong cinnamon and clove smell the most notorious characteristic. The most similar and, probably, most closely related species is $P$. aureum which was discovered not too far from where $P$. raoi grows; it also shares similar features with $P$. marniae (Fig. 3). Nonetheless, the white flowers with a short channeled tail of the dorsal sepal, the brownishpurple, thickened along the middle tails of the lateral sepals, the lower margin of the petals with a subacute angle near the middle and the detectable cinnamon and clove fragrance immediately separate it from similar species (Table 1; sources Luer 1980, 1987, 1988, 1989, 1991, 1994, 1995, 1998, 2006, Merino, Doucette \& Pupulin 2010, Kolanowska \& Szlachetko 2013). 
Table 1. Comparison between Porroglossum raoi and other related species.

\begin{tabular}{|c|c|c|c|c|c|c|}
\hline Species & $\begin{array}{l}\text { Dorsal sepal } \\
\text { tail length }\end{array}$ & $\begin{array}{c}\text { Lateral } \\
\text { sepals tails }\end{array}$ & Lip & Lip callus & Petals & Fragrance \\
\hline P. raoi & $3 \mathrm{~mm}$ & $\begin{array}{l}\text { Thickened, } \\
\text { subclavate, } \\
\text { brownish- } \\
\text { purple }\end{array}$ & $\begin{array}{l}\text { White, obtrullate, } \\
\text { suffused with } \\
\text { dispersed purple } \\
\text { dots }\end{array}$ & $\begin{array}{l}\text { Broadly, } \\
\text { thickened, } \\
\text { with a shortly } \\
\text { elevated keel }\end{array}$ & $\begin{array}{l}\text { Translucent yellow with } \\
\text { red-purple midvein, the } \\
\text { lower margin with a } \\
\text { subacute angle near the } \\
\text { middle }\end{array}$ & $\begin{array}{l}\text { Strong } \\
\text { cinnamon } \\
\text { and clove }\end{array}$ \\
\hline P. aureum & $2 \mathrm{~mm}$ & $\begin{array}{l}\text { Slender, } \\
\text { thickened } \\
\text { along the } \\
\text { middle, yellow }\end{array}$ & $\begin{array}{l}\text { Yellow, cuneate, } \\
\text { glabrous }\end{array}$ & Tall, thick & $\begin{array}{l}\text { Translucent yellow with } \\
\text { a dark yellow midvein, } \\
\text { margins obtusely angled } \\
\text { near the middle }\end{array}$ & $\begin{array}{l}\text { Not } \\
\text { detected }\end{array}$ \\
\hline P. hoeijeri & $4 \mathrm{~mm}$ & $\begin{array}{l}\text { Slender, } \\
\text { purplish }\end{array}$ & $\begin{array}{l}\text { Rose, cuneate, } \\
\text { broadly rounded, } \\
\text { shortly pubescent }\end{array}$ & Tall, rounded & $\begin{array}{l}\text { Translucent orange, } \\
\text { the margins with acute } \\
\text { angles below the middle }\end{array}$ & $\begin{array}{l}\text { Not } \\
\text { detected }\end{array}$ \\
\hline P. amethystinum & $2 \mathrm{~mm}$ & $\begin{array}{l}\text { Slender, } \\
\text { slightly } \\
\text { thickened } \\
\text { apically, } \\
\text { orange }\end{array}$ & $\begin{array}{l}\text { White, subfused } \\
\text { and dotted with } \\
\text { dark purple, apex } \\
\text { purple black, } \\
\text { cuneate }\end{array}$ & Low, smooth & $\begin{array}{l}\text { Translucent with brown } \\
\text { midvein, margins } \\
\text { obtusely angled near } \\
\text { the middle }\end{array}$ & $\begin{array}{l}\text { Not } \\
\text { detected }\end{array}$ \\
\hline P. marniae & $2 \mathrm{~mm}$ & $\begin{array}{l}\text { Thickened, } \\
\text { subclavate, } \\
\text { white }\end{array}$ & $\begin{array}{l}\text { Dark purple, } \\
\text { white at the } \\
\text { base, obovate, } \\
\text { microscopically } \\
\text { pubescent }\end{array}$ & $\begin{array}{l}\text { Low, } \\
\text { longitudinal, } \\
\text { brown }\end{array}$ & $\begin{array}{l}\text { Translucent white, } \\
\text { obtuse angles below the } \\
\text { middle }\end{array}$ & $\begin{array}{l}\text { Not } \\
\text { detected }\end{array}$ \\
\hline P. nutibara & absent & $\begin{array}{l}\text { Thickened, } \\
\text { subclavate, } \\
\text { yellow }\end{array}$ & $\begin{array}{l}\text { White and red } \\
\text { minutely } \\
\text { pubescent above } \\
\text { the middle, } \\
\text { obovate }\end{array}$ & $\begin{array}{l}\text { Tall, rounded, } \\
\text { longitudinal, } \\
\text { glabrous }\end{array}$ & $\begin{array}{l}\text { Translucent white, } \\
\text { margins with obtuse } \\
\text { angles below the middle }\end{array}$ & $\begin{array}{l}\text { Not } \\
\text { detected }\end{array}$ \\
\hline P. olivaceum & $2-3 \mathrm{~mm}$ & $\begin{array}{l}\text { Slender, } \\
\text { orange-red }\end{array}$ & $\begin{array}{l}\text { Yellow, dark } \\
\text { purple and } \\
\text { densely short- } \\
\text { pubescent on } \\
\text { the distal half, } \\
\text { cuneate }\end{array}$ & $\begin{array}{l}\text { Tall, rounded, } \\
\text { longitudinal }\end{array}$ & $\begin{array}{l}\text { Translucent yellow } \\
\text { or light brown, with a } \\
\text { darker midvein, lower } \\
\text { margins with an acute } \\
\text { angle near the middle }\end{array}$ & $\begin{array}{l}\text { Not } \\
\text { detected }\end{array}$ \\
\hline
\end{tabular}

ACKNOWLEDGEMENTS. We acknowledge Universidad de Las Americas (UDLA) for funding research on orchids in Ecuador. The Ministerio del Ambiente del Ecuador is acknowledged for issuing the Environmental Research Permit No. 008-2016-IC-FLO-DNB/MA. We also want to thank Mr. Velliyur "Malli" Rao and his wife for being vital supporters and donors which made possible the Dracula Reserve as well as other reserves managed by Ecominga Foundation. Also Ecominga Foundation for working in conservation of orchids in situ by preserving forests before being cut down. Finally, we are grateful to the Editor and the anonymous reviewers for suggestions on the manuscript.

\section{LiterATURE CITED}

Chase, M. W., Cameron, K. M., Freudenstein, J.V., Pridgeon, A. M., Salazar, G., van den Berg, C. \& Schuiteman, A. (2015). An updated classification of Orchidaceae. Botanical Journal of the Linnean Society, 177, 151-174.

Dodson, C. H. (2003). Native Ecuadorian orchids. Vol. 4:

Oncidium-Restrepiopsis. Sarasota, Florida: Dodson Trust.

Doucette, A., McDaniel, J., Merino, G., Portilla, J. \&
Cameron, K. (2015). Two new Masdevallia species and a new Porroglossum (Orchidaceae: Pleurothallidinae) from Zamora-Chinchipe, Ecuador. AOS-Orchids (Lindleyana), 84(8), 504-511.

Karremans, A. P. (2016). Genera Pleurothallidinarum: an updated phylogenetic overview of Pleurothallidinae. Lankesteriana, 16(2), 219-241.

Kolanowska, M. \& Szlachetko, D. L. (2013). A new species of Porroglossum (Orchidaceae, Pleurothallidinae) from 
Colombia. Polish Botanical Journal, 58(2), 629-632.

Luer, C. A. (1980). Miscellaneous new species in the Pleurothallidinae (Orchidaceae). Phytologia, 46(6), 374-381.

Luer, C. A. (1987). Icones Pleurothallidinarum IV. Systematics of the genus Porroglossum. Monographs in Systematic Botany from the Missouri Botanical Garden, 24, 25-90.

Luer, C. A. (1988). Icones Pleurothallidinarum V. Systematics of Dresslerella and Scaphosepalum. Addenda to Porroglossum. Monographs in Systematic Botany from the Missouri Botanical Garden, 26, 108-109.

Luer, C.A. (1989). Icones Pleurothallidinarum VI. Systematics of Pleurothallis subgenus Ancipitia, subgenus Scopula and Trisetella. Addendum to Porroglossum. Monographs in Systematic Botany from the Missouri Botanical Garden, 31, 124-125.

Luer, C. A. (1991). Icones Pleurothallidinarum VIII. Systematics of Lepanthopsis, Octomeria subgenus Pleurothallopsis, Restrepiella, Restrepiopsis, Salpistele, and Teagueia: addenda to Platystele, Porroglossum and Scaphosepalum (Orchidaceae). Monographs in Systematic Botany from the Missouri Botanical Garden, 39, 152-156.

Luer, C. A. (1994). Icones Pleurothallidinarum XII. Systematics of the genus Lepanthes subgenus Brachycladium and Pleurothallis subgenus Aenigma subgenus Elongatia subgenus Kraenzlinella. Addenda to Dracula, Lepanthopsis, Myoxanthus, Platystele, Porroglossum and Trisetella. Monographs in Systematic Botany from the Missouri Botanical Garden, 52, 134.

Luer, C. A. (1995). Icones Pleurothallidinarum XII. Systematics of the genus Brachionidium. Addenda to Dresslerella, Platystele and Porroglossum. Monographs in Systematic Botany from the Missouri Botanical Garden, 24, 144-145.
Luer, C. A. (1998). Icones Pleurothallidinarum XVII: Pleurothallis Subgenus Pleurothallis Sections Pleurothallis and Acroniae, Pleurothallis Subgenera. Addenda to Dracula, Lepanthes, Masdevallia, Porroglossum and Scaphosepalum. Monographs in Systematic Botany from the Missouri Botanical Garden, 72, 114-115.

Luer, C. A. (2006). Icones Pleurothallidinarum XXVIII: A reconsideration of Masdevallia, and the systematics of Specklinia and Vegetatively similar taxa (Orchidaceae). Addendum to Porroglossum. Monographs in Systematic Botany from the Missouri Botanical Garden, 105, 253254.

Luer, C. A. (2010). Icones Pleurothallidinarum XXXI: Lepanthes of Bolivia. Systematics of Octomeria species north and west of Brazil. Monographs in Systematic Botany from the Missouri Botanical Garden, 120, 147153.

Luer, C. A. (2011). Miscellaneous New Species in the Pleurothallidinae (Orchidaceae) Excluding Species from Brazil. Harvard Papers in Botany, 16(2), 341345.

Luer, C. A. \& Thoerle, L. (2012). Miscellaneous New Species in the Pleurothallidinae (Orchidaceae). Harvard Papers in Botany, 17(2), 333-368.

Luer, C. A. \& Thoerle, L. (2013). Miscellaneous New Species in the Pleurothallidinae (Orchidaceae). Harvard Papers in Botany, 18(2), 183-185.

Merino, G., Doucette, A. \& Pupulin, F. (2010). New species of Porroglossum (Orchidaceae: Pleurothallidinae) from Ecuador. Lankesteriana, 9(3), 459-466.

Schlechter, R. (1920). Beschreibungen neuer Arten: Porroglossum colombianum. Repertorium specierum novarum regni vegetabilis, Beihefte, 7, 83.

Sweet, H. R. (1970). Orquídeas andinas poco conocidas. IV. Porroglossum Schltr.. Orquideologia, 5, 155-170. 